UDC 33

\title{
SUSTAINABLE TOURISM DEVELOPMENT MASTER PLAN IN LOMBOK ISLAND: AN ECONOMIC AND ENVIRONMENTAL CONTRADICTION
}

\author{
Nazwin Asfarony Hendra \\ Master's Program of Public Administration, Faculty of Administrative Science, \\ University of Brawijaya, Indonesia \\ E-mail: asfaronyhendra@gmail.com
}

\begin{abstract}
Sustainable development is becoming more relevant to be applied in various development sectors. As a matter of fact, Nusa Tenggara Barat Province also implemented this model to develop its tourism sector through a good planning. This phenomena occurred due the complexity in the correlation between tourism and sustainable development which has not yet reached a consensus. As the implication, sustainable development implemented for tourism sector in NTB (particularly Lombok Island) has managed to achieve only economic targets, while it often gave negative impacts for the environment. Therefore, this research was necessary to conduct in order to evaluate the planning of the Sustainable Tourism Master Plan Lombok 2015-2019. This research employed a qualitative method which data were analyzed using an interactive data analysis and SWOT analysis.
\end{abstract}

\section{KEY WORDS}

Development planning, sustainable development, sustainable tourism, Lombok Island.

Nowadays, the concept of sustainable development is becoming more relevant to be applied in various sectors of development, one of which is the tourism sector. A number of research describe the correlation between the concept of sustainable development and the development of tourism sector (Moscardo, et.al., 2013). Description about this complex, contradictory and broad relationship can be used to identify various consensus on this matter.

Explicit consensus for the identification of this matter is expected grow the awareness upon the intensive pressure demanding for thorough consideration about sustainable development issues in the planning, development and management of tourism sector. In addition, it is also important to take the anxiety upon the possible negative impacts of tourism for the environment (Mason, 2008 in (Moscardo, et.al., 2013). Besides, there have been biases in the movements within sustainable tourism environment and the consensus upon the needs of theoretical supports and more comprehensible framework to understand certain process and conditions that will positively affect the tourism sector (Moscardo, 2008; Saarinen, 2006; Wall \& Mathieson, 2006 in Moscardo, et.al., 2013).

Regarding to this explanation, it can be seen that poor tourism management might give major implications for the management of tourism sector in Indonesia. For instance, in the tourism sector of Lombok Island, NTB, there have been environmental degradation, exploitation, disparity, unemployment, unstable local economic condition, pollution and poor road infrastructure which should be taken into consideration during the consensus identification in order to apply the sustainable tourism development.

Starting from 2013, the implementation of sustainable tourism development in Lombok Island has only created stronger economic development. As seen in the economic report of NTB, there has been an increase in the economic development from 5.82 percent (2016) to 6.00 percent (2017) as the number of tourism visit was also high. It implies that tourism sector has been able to give significant contribution in economic development of regions in Indonesia. .

Unfortunately, in a parallel way, this improvement has received a number of criticisms, one of which is related to the environmental damages as the negative effect of improvement in tourism sector. As explained by the Global Sustainable Tourism Council of Germany in 
2015 , NTB is facing serious problems such as environmental pollution and litters due to poor attitudes of visitors related to this issue (Harian Terbit, 2015), poor accessibility, low satisfactory level, inadequate tourism management, massive use of water spring, low quality of the water and weak public participation (GSTC, 2016).

In addition, the economic development in NTB also created another problem related to the intensive operational activities of hotels which directly leads to lower air quality and alarming air pollution caused by motor vehicle emission. Regarding to the data published on ww.dislhk.ntbprov.go.id, the air quality index in NTB has declined from 92.27 in 2015 to 81.2 in 2016. This decline was caused by massive number of visitors in 2016 of around 2.9 million people (www.kicknews.today) which led to the decline in the air quality in the same year.

Those problems have triggered criticism toward the use of current development model in creating a sustainable tourism development in NTB. Thus, there has to be a clear consensus upon the planning and development of the tourism sector in accordance to the principles of sustainable development program. Prior to the implementation of this concept, a research should be conducted to evaluate the planning process applied in NTB related to its Sustainable Tourism Master Plan Lombok (STMP Lombok 2015-2019), including thorough evaluation on any detailed processes and identifications of the inhibiting and contributing factors in order to give precise recommendations related to the implementation of the new concept or strategy to achieve the goals of the sustainable tourism development.

\section{METHODS OF RESEARCH}

This research employed a qualitative method using descriptive approach. Research data were collected through interviews with informants, observations and documentation. Data collection was conducted in The Department of Tourism of NTB Province, Bappeda of NTB, GIZ Germany in NTB and favorite tourism attractions which were selected based on the number of visitors. There were two different data analysis methods used to analyze the obtained data. An interactive data analysis was employed to analyze the obtained data related to the planning process, while SWOT analysis was used to identify the inhibiting and contributing factors of the planning process. SWOT analysis was administered to the results of interviews, documentation, and statistical calculation of important variables.

\section{RESULTS AND DISCUSSION}

The Planning Process of the Sustainable Tourism Development in Lombok Island. The result evaluation shows that STMP process in Lombok has been working based on the rational and comprehensive procedures; assessment of the current condition, goal determination, identification of prospective stakeholders, determination of the strategies, and the planning $f$ actions. In an explicit context, this process is included in the synoptic planning model proposed by Hudson (1979). Synoptic planning is a model that has been used in administering good planning process, in which planning is regarded as a scientific, rational and non-political process. Scientific rationale refers to the method used to determine the best way to achieve certain goal by choosing the correct answer based on the review of possible consequences and alternative solution. Whilst, political activity refers to any planning activites which are rather technical instead of political (Hadi, 2013).

Assessment on the Current Condition. Various references and empirical facts suggest that assessment on the current condition should be done prior to the planning process. The assessment should be comprehensively done, considering the fact that the sustainable development of Lombok is an across-sector responsibility. Suharto (2015) mentioned that identification on the problems that should be comprehensively addressed is the first step in planning a development program. In STMP Lombok, the identification was done based on the acceptable research principles and through focus group discussion, resulting to a list of problems that should be considered in determining the goals. 


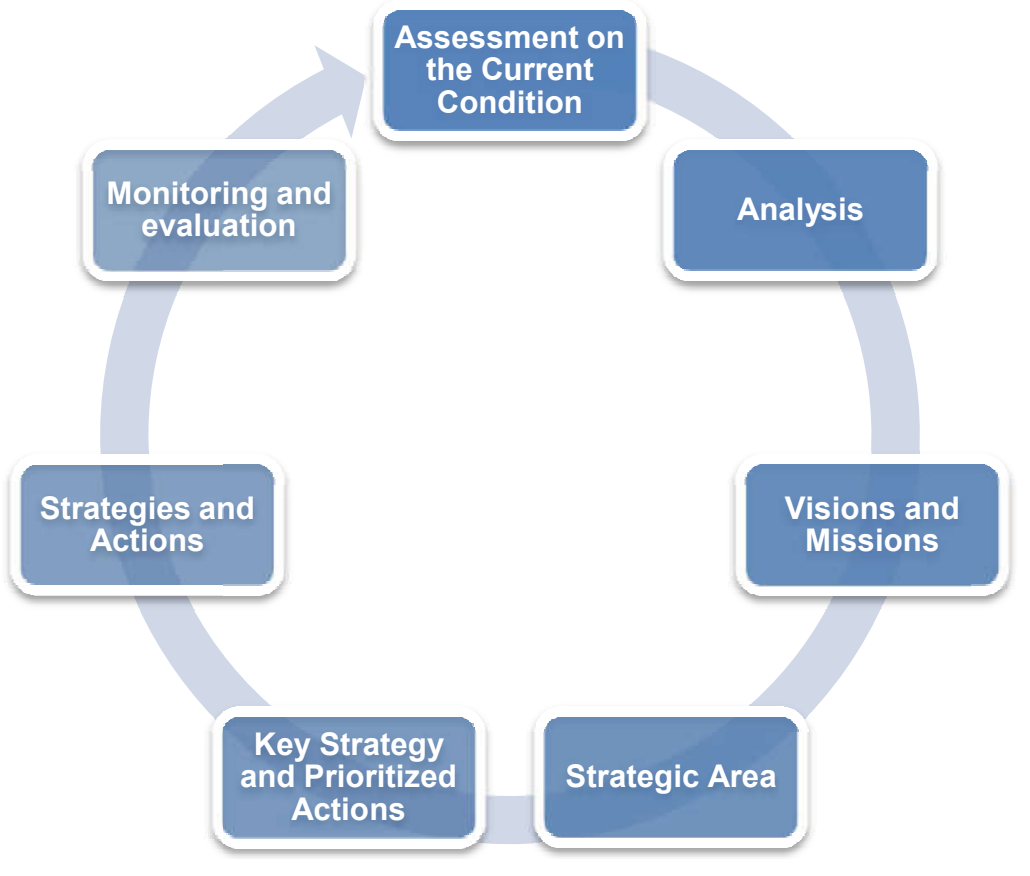

Figure 1 - The Process of STMP Planning

Source: STMP Lombok 2015-2019

Determining the Goals of Sustainable Tourism Development. Goals of STMP Lombok were generally determined based on the result of a constitutional reflection. Thus, the goals were determined in accordance to the current regulations, including international, national and regional regulations. Those regulations were divided into four categories; mandates, international background, WTO ethics, government program, green tourism idea, regional planning or RIPPARDA NTB 2013-2028 written in the document or draft on the initiation of green tourism concept in Lombok (the outline of the sustainable tourism master plan of Lombok).

In relation to the planning process proposed by Mayer (1985), the concept of the goal determination is in line with the real empirical facts as emphasized by Mayer (1985) that goals should be determined in accordance with various references. The references refer to any international, national and regional regulations that apply. Hence, there has to be strong supportive sources before the goals are applied in a collective way through some forums.

Regarding to those conditions, the vision of STMP Lombok was formulated as "Lombok as an environmental and cultural tourism destinations with high competitiveness and sustainability" and the missions were formulated in accordance with various references as follows.

Table 1 - The Goals of STIMP Lombok 2015-2019

\begin{tabular}{|c|c|c|}
\hline NO. & Prioritized Strategy & Goals \\
\hline 1. & $\begin{array}{l}\text { The Development of Tourism } \\
\text { Destinations in Lombok Island }\end{array}$ & $\begin{array}{l}\text { Goal 1: Enhancing the participation of local community in developing the } \\
\text { tourism destinations } \\
\text { Goal 2: Developing unique, clean, authentic and sustainable tourism attractions } \\
\text { Goal 3: Developing safe and comfortable tourism attractions }\end{array}$ \\
\hline 2. & Tourism Marketing & Goal 4: Improving the quality of visits and visitors' satisfaction. \\
\hline 3. & Tourism Industry in Lombok & $\begin{array}{l}\text { Goal 5: Establishing tourism institutions with adequate human resources and } \\
\text { professional workers } \\
\text { Goal 6: Establishing tourism institutions that are supported by communities with } \\
\text { adequate environmental awareness }\end{array}$ \\
\hline 4. & Management of Tourism in Lombok & $\begin{array}{l}\text { Goal 7: Creating a conducive working atmosphere that supports tourism } \\
\text { industries in providing high creative and innovative products and service } \\
\text { Goal 8: Creating green tourism-oriented working atmospheres that regard the } \\
\text { principles of sustainable tourism development. }\end{array}$ \\
\hline
\end{tabular}

Source: STMP Lombok 2015-2019. 
The Identification of Stakeholders. The planning procedure proposed by Mayer did not allow the identification of stakeholders to take place. Whereas, the planning was expected to be a rational, scientific, and comprehensive process. This planning was supposed to be a comprehensive process that includes the identification of stakeholders into the Mayer process. The results of interviews with informants show that the planning of tourism development is an across-sector activity (Gusia, 2017) which indicates that the comprehensive process should take into account various aspects of sustainable tourism development and involve the stakeholders. The identification of the stakeholders is determined by the result of assessment in the field for the result lead to the stakeholders who support the functions and responsibilities related to the intended resolution.

STMP Lombok has involved stakeholders by adopting the principles suggested by by Nurfatriani, et al. (2015), including (1) Primary stakeholders that consisted of The Department of Tourism of NTB, Bappeda NTB, and the Department of Tourism in the district level as the ones who would receive the positive and negative effects of the development, (2) Key stakeholders which consisted of Bappenas and the Department of Tourism which hold the authority in making decisions, (2) Secondary stakeholders which consisted of international organization, local community, managers of tourism attraction, practitioners, local NGOs, international NGOs and business associations as the mediators in the process of decision making as they have big concerns about this matter but they do not have any direct access to the process.

The Strategic Development of Sustainable Tourism. Regarding to the result of interviews, it is known that STMP Lombok formulated its strategies based on the result of SWOT analysis to determine the position of tourism attractions and to be used as the insights in determining appropriate programs based on proper consideration. The strategies set by STMP Lombok generally concern about the tourism development both in a sustainable and non-sustainable ways.

The sustainable tourism master plan of Lombok adapted the strategy of priorities and combinations among several different strategies. The strategy of priority was formulated based on the level of urgency, feasibility, and aspects that needed intensive and continuous attention. Kurniasih (2005) in Hilamah dan Karyana (2017) stated that the scale of priority should be applied in determining the urgency, benefits, maintenance and the coverage of certain projects in the development process and in the utilization of the available resources. Generally, the strategies set by STMP Lombok consist of:

1. Strategies to develop sustainable tourism sector with emphasizes on community participation, community empowerment, local economy enhancement, environmental sustainability, local culture, environmental adaptation, prevention upon exploitation and safety enhancement by involving pemswakarsa pariwisata.

2. Marketing strategies of sustainable tourism sector that emphasize the use of guidedmarketing and promotion which accommodate the most promising tourism interests.

3. Strategies for the sustainable tourism industry that emphasize the improvement of labor quality and public participation in the process of tourism attraction development by involving the role of stakeholders.

4. Strategies for sustainable tourism institution development with emphasizes on the development of local products, accessible funding for culinary sector, integration of local product, and the availability of incentive and certification for local business.

Action Plans. Mayer (1985) explained that in this phase, the planning of actions should be done to achieve the intended targets. However, determining the best actions is not easy since there are various issues to consider; parties appointed to run the programs usually are non-government parties delegated by the Department of Regional Development of NTB which process is still regarded inefficient for its high costs.

In addition, the determination of the actions is the most controversial step in the planning process. This step deals with different commitments that give decision makers new perspectives upon the previously made decisions. Previous issues might have been well solved yet they might become unstable. Besides, debates upon alternative actions, interests, or consequences might lead to re-identification of some aspects such as the goals and 
targets, needs assessment, and other alternative, leading to longer time spent for the planning stage. In another word, this stage is a political process to meet the technical necessities of various parties in order to form new actions.

In this action planning, Mayer stated that choosing the best action is not easy even though this step is rather social than technical or rational. It is important to note that this step should be administered carefully based on the ethics of decision making in order to obtain the best results. Unfortunately, the action plans made by STMP Lombok are rather paradox, in which the main goal is to create a sustainable tourism sector but the emphasizing is on the marketing method that give the highest profit. At this point, interests of various parties might interrupt the process as explained by Mayer.

The Contributing and Inhibiting Factors of the Sustainable Tourism Planning. In this research, the contributing and inhibiting factors were determined from the result of SWOT analysis. Variables measured in the SWOT analysis were identified from the results of interviews and documentation. The scoring procedure was designed based on the most important variable.

The contributing factors have been identified including; the availability of regulations to be used as the basic considerations in the decision making done by STMP Lombok, favorable tourism atmosphere as seen from the increase in the number of visitors each year, and strong commitment of tourism institutions as reflected in the green-tourism program. Regarding to organizational commitment, Hadi (2013) explained that a development is stated successful when it comes from the top, which refers to a development that is initiated by central government distributed to certain system that fits the principles of decentralization.

The inhibiting factors identified including the rapid development of tourism sector while society's awareness on the importance of the sustainable tourism development was considered low, limited amount of fund available for this sector and the weal synergy among relevant parities. Out of those factors, society's inadequate awareness and the limited amount of fund available are factors that give significant implication to the product. The poor awareness of the society upon this matter negatively affects the process since engaging the society to share a similar view on this matter is a challenging process since the society tends to think of only the short-term benefit that they will get from the program (Gusia, 2017).

Furthermore, the limited amount of available fund has been considered inadequate to implement the whole package from the planning up to the policy implementation. This problem has led to incomplete implementation of the policies made by STMP Lombok. The policy was made in the form of governor regulation of NTB. Unfortunately, the this decision was not implemented because there were a limited amount of fund available and different perceptions about the conditions of decision making. The Department of Tourism of NTB shared a different perspective (dualism) from GIZ related to the conditions in making decisions.

Those problems have resulted to the unavailability of the governor regulation which is described into two categories as follows.

The Weakest Point of Policy Implementation. Action plans made by each OPD on charge would not meet the ones made by STMP. There has been an indication that the development of tourism sectors in Lombok Island was made by the government of the province (Rinjani Geopark). It implies that various ideas in the sustainable tourism development were not made by STMP Lombok but Rinjani Geopark, yet similarities were found among them. Biases occurred due to the unclear legal status of STMP which occurred as the main cause of the failure of STMP in implementing various decisions as stakeholder (lead agency).

The Strongest Point of Policy Implementation. There have been a number of different rationales on the absence of STMP policy, one of which is related to the geographical condition of NTB province which consists of Lombok Island and Sumbawa Island. Some informants stated that this absence might be caused by the fact that development was mainly focused in only Lombok Island. Furthermore, some informants also stated that governor regulations should be made based on collectiveness and equality principles. Governor 
regulations can only be implemented when STMP also involve Sumbawa Island in the planning.

Formulation of Strategies. Based on the result of SWOT analysis, various processes have been implemented, including the identification, scoring, IE matrix up to the formulation of strategies. There have been some penetration and development strategies proposed based on S-0, S-T, W-O and W-T strategies. Some prioritized strategies include:

W-T Strategies:

- Developing the infrastructure with the main focus on the sustainable development.

- Minimizing the impact of climate change through the implementation of local rules.

- Implementing the tourist-free day once in a year to let the environment recover.

- Making an agreed perception and commitment about the importance of environmental friendly tourism attractions across regional government.

The rationality of $\mathrm{W}-\mathrm{T}$ as a prioritized strategy relates with the fact that conservation process is impossible to go hand in hand with exploitation. Thus, conservation should be started by temporary closure of tourism activities. Regarding to this idea, it is necessary to prioritize ecological improvements (environmental) as throughout this time, tourism sector has been only focusing on the economic aspect. Therefore, a balance should be made by giving certain pressure in one side in order to make improvement in the other side.

\section{CONCLUSION}

In a simpler way, it can be concluded that STMP Lombok has implemented the development process comprehensively yet within a longer time. Compared to Mayer process (1985), this process does not share a complete relevance, yet Mayer proposed a more flexible planning model for in the model, the determination of goals, assessment and determination of the strategies can initiate the planning process by considering the current social conditions.

Deeper understanding on Mayer's model obtains a more comprehensive insight that the model and the one implemented by STMP Lombok share relevancy since Mayer gives broader room for this aspect. However, within the context of sustainable development, Mayer does not give adequate opportunities for the planning of the sustainable development. The assessment stage is only done to analyze the socio-economic conditions, without analyzing the environmental conditions. As the implication, the development of sustainable tourism development is merely seen as compensation upon environmental damages that occurred.

Besides sustainable tourism development is seen as a compensatory gimmick, basically, the adoption of sustainable development principles is not completely meant to reach good intentions. A more radical analysis has resulted to the finding of grand narratives that simultaneously protect the long-term economic programs for economic programs are closely related to resource exploration. In short, the notion of sustainable tourism development started from anxiety upon the long-term economic development. Higher rate of resource decrease gives a parallel impact to the decrease in tourism activities which negatively affects the economic profit. Basically, it is an economic strategy that works in the name of sustainable tourism development which is a result of anxiety upon unstable economic activities by using the fact about environmental damages and limited natural resources.

It should be taken into account that policies are the key to the implementation of certain plans. The power of planning relies on the policies as policies are able to give significant implications toward the implementation of the sustainable tourism development. Thus, within practical and theoretical perspective, policies should be determined prior to further development as explained by Mayer (1985) that planning is closely related to policy making and they are often misinterpreted. It can be implied from the result of this research that policies should be implemented first. It is also stated in the Regulation of the Ministry of State Affairs Number 86 in 2017 that the final process of planning activities should be determined. Yet, dualism views among stakeholders should be solved to create a more comprehensive view in order to guarantee the success of a policy implementation. 


\section{REFERENCES}

1. Mayer, R. R. (1985). Policy and Program Planning, A Developmental Perspective. New Jersey: Prentice-Hall Inc.

2. Peraturan Daerah Provinsi Nusa Tenggara Barat Nomor 7 Tahun 2013 Tentang Rencana Induk Pembangunan Kepariwisataan Daerah Tahun 2013-2028.

3. Rangkuti, F. (2008). Analisis SWOT Teknik Membedah Kasus Bisnis: Reorientasi Konsep Perencanaan Strategis untuk Menghadapi Abad 21. Jakarta: PT. Gramedia Pustaka.

4. Sugiyono. (2014). Metode Penelitian Kuantitatif, Kualitatif, dan R\&D. Bandung: Alfabeta.

5. Sugiyono. (2015). Memahami Penelitian Kualitatif. Bandung: Alfabeta..

6. Suharto, E. (2015). Membangun Masyarakat Memberdayakan Rakyat: Kajian Strategis Pembangunan Kesejahteraan Sosial dan Pekerjaan Sosial. Bandung: Reflika Aditama.

7. Harian Terbit, Masalah Sampah Jadi Tantangan Bagi Pariwisata Pulau Lombok. Retrieved from http://lifestyle.harianterbit.com/lifestyle/2015/10/15/44444/80/38/MasalahSampah-Jadi-Tantangan-Bagi-Pariwisata-Pulau-Lombok

8. Hadi, S. (2013). Dimensi Lingkungan Perencanaan Pembangunan. Yogjakarta: Gadjah Mada University Press.

9. Nuratriani, et al. (2015). Analisis Pemangku Kepentingan Dalam Transformasi Kebijakan Fiskal Hijau (Stakeholder Analysis in Green Fiscal Policy Transformation). Jurnal Analisis Kebijakan Kehutanan. 12(2), 105-124. 